\title{
Penguatan kelembagaan desa adat di Kampung Lubuk Jering Kecamatan Sungai Mandau Kabupaten Siak
}

\author{
Abdul Sadad ${ }^{1 *}$, Dadang Mashur'1, \& Tito Handoko² \\ 1Jurusan Ilmu Administrasi Negara, Fakultas Ilmu Sosial dan Ilmu Politik, Universitas Riau \\ 2Jurusan Ilmu Pemerintahan, Fakultas Ilmu Sosial dan Ilmu Politik, Universitas Riau \\ *abdulsadad13@gmail.com
}

\begin{abstract}
Abstrak. Pengabdian ini bertujuan untuk memberikan penguatan kelembagaan kampung adat dalam penyelenggaraan pemerintahan, pembangunan dan pelayanan kepada masyarakat di Kampung Lubuk Jering Kecamatan Sungai Mandau. Masalah yang terjadi diakibatkan oleh semakin kompleknya tata kehidupan di tengah masyarakat kampung adat sebagai akibat dari pengaruh urbanisasi penduduk dari daerah lain. Kampung adat di Kabupaten Siak sebagai salah satu bentuk sistem pemerintahan tradisional di Indonesia yang banyak mengalami perubahan. Perubahan itu menyangkut berbagai aspek kehidupan sosial yang menyentuh nilai, norma, sikap dan pola perilaku masyarakatnya. Metode yang digunakan adalah metode penyuluhan. Pelaksanaan pengabdian masyarakat dalam rangka penguatan kelembagaan adat di Kampung Lubuk Jering Kecamatan Mandau dapat disimpulkan telah berhasil memberikan penyuluhan. Keberhasilan ini antara lain ditunjukkan oleh adanya kesesuain materi dengan kebutuhan aparatur pemerintahan desa dan masyarakat dalam usaha penguatan kelembagaan adat di Kampung Lubuk Jering Kecamatan Sungai Mandau Kabupaten Siak. Kemudian adanya respon yang positif (70\%) dari peserta berdasarkan kuisioner yang dibagikan, yang ditunjukkan dengan pertanyaan dan tanggapan yang diberikan selama pengabdian. Sebagian besar peserta telah memahami arti pentingnya penguatan kelembagaan adat di Kampung Lubuk Jering Kecamatan Sungai Mandau Kabupaten Siak.
\end{abstract}

Kata kunci: kebijakan; peraturan; pemerintahan; pelayanan

\begin{abstract}
This service aims to provide institutional strengthening of traditional villages in the administration, development and service to the community in Lubuk Jering Village, Sungai Mandau District. The problem that occurs is due to increasingly complex systems of life in the midst of indigenous village communities as a result of the influence of urbanization from other regions. Traditional villages in Siak Regency are one form of traditional government system in Indonesia that has undergone many changes. The change concerns various aspects of social life that touch the values, norms, attitudes and patterns of behavior of the people. The method used is the extension method. The implementation of community service in the context of strengthening customary institutions in Lubuk Jering Village, Mandau District can be concluded to have successfully provided counseling. This success was demonstrated, among others, by the compatibility of the material with the needs of village government officials and the community in an effort to strengthen Then there was a positive response (70\%) of participants based on the questionnaire distributed, which was indicated by the questions and responses given during the service. Most of the participants understood the importance of strengthening adat institutions in Kampung Lubuk Jering, Sungai Mandau District, Siak Regency.
\end{abstract}

Keywords: policy; regulation; government; service

To cite this article: Sadad, A., D. Mashur, \& T. Handoko. 2019. Penguatan kelembagaan desa adat di Kampung Lubuk Jering Kecamatan Sungai Mandau Kabupaten Siak. Unri Conference Series: Community Engagement 1: 684689 https://doi.org/10.31258/unricsce.1.684-689

(C) 2019 Authors

Peer-review under responsibility of the organizing committee of Seminar Nasional Pemberdayaan Masyarakat 2019 


\section{PENDAHULUAN}

Otonomi daerah atau yang disebut desentralisasi dalam menyelenggarakan pemerintahan di Indonesia memberikan kesempatan dan keleluasaan kepada daerah untuk menyelenggarakan rumah tangganya sendiri. Hal ini sejalan dengan pasal 18 Undang-undang Dasar 1945 antara lain menyatakan bahwa pembagian daerah Indonesia atas daerah besar dan kecil dengan bentuk dan susunan pemerintahannya ditetapkan dengan undangundang. Dengan demikian dapat di pahami bahwa makna eenheidsstaat berlaku pada pembagian daerah, artinya tidak ada staat di dalam staat.

Menyangkut tentang kesatuan-kesatuan masyarakat hukum adat, ketentuan tersebut termaktub dalam pasal 18B Ayat 2 yang menyebutkan bahwa Negara mengakui dan menghormati kesatuan-kesatuan masyarakat hukum adat beserta hak-hak tradisionalnya sepanjang masih hidup dan sesuai dengan perkembangan masyarakat dan prinsip Negara Kesatuan republik Indonesia yang diatur dalam Undang-undang.

Jika dilihat dari penjelasan tersebut dapat dikatakan bahwa keberadaan masyarakat hukum adat itu sendiri tergabung dalam suatu ikatan kewilayahannya masing- masing berdasarkan hak asal-usul seperti nagari, gampong atau marga yang sekarang ini lebih dikenal dengan desa adat. Desa adat merupakan susunan asli yang mempunyai hak-hak asal usul berupa hak mengurus wilayah (hak ulayat) dan mengurus kehidupan masyarakat hukum adatnya. Dalam menjalankan pengurusan tersebut, Desa adat mendasari diri pada hukum adat untuk mengatur dan mengelola kehidupan masyarakat hukum adat dan wilayah adatnya.

Desa adat merupakan kekayaan budaya yang ada di Indonesia. Keberadaannya adalah sebagai wadah pelestarian norma-norma dan kearifan lokal yang menjadi potensi dalam rangka menjaga identitas dan keberagaman budaya yang ada di desa. Untuk mendapatkan pengakuan sebagai kesatuan masyarakat adat maka ada beberapa kriteria yang harus dipenuhi yaitu memiliki wilayah adat, pemerintahan adat, benda/kekayaan adat, hukum adat (pasal 1 ayat 1 UU No 6 Tahun 2014 tentang desa).

Kabupaten Siak merupakan salah satu kabupaten yang masih memiliki masyarakat hukum adat. Upaya Pemerintah Kabupaten Siak dalam melestarikan keberadaan masyarakat hukum adat tersebut termaktub dalam Peraturan Daerah Kabupaten Siak Nomor 2 Tahun 2015 Tentang Penetapan Kampung adat di Kabupaten Siak. Di jelaskan dalam Pasal 1 Perda Kabupaten Siak No. 2/2015 bahwa "Kampung adat adalah susunan asli yang mempunyai hak asal-usul berupa hak mengurus wilayah dan mengurus kehidupan masyarakat hukum adatnya".

Adapun tujuan untuk menghidupkan kembali peranan tokoh adat dalam penyelenggaraan pemerintahan, pembangunan dan pelayanan kepada masyarakat, disebabkan oleh semakin kompleknya tata kehidupan di masyarakat sebagai pengaruh urbanisasi penduduk dari daerah lain. Memberikan peran dan fungsi kepada Kepala Kampung adat dan Tokoh Adat untuk dapat mengayomi kehidupan masyarakat yang lebih optimal.

Pemerintah Kabupaten Siak telah menetapkan 8 Desa menjadi Kampung adat, salah satunya adalah Kampung Lubuk Jering Kecamatan Sungai Mandau. Adapun yang menjadi fokus pengabdian adalah pada kelembagaan Kampung adat Lubuk Jering yang mana terdapat permasalahan yaitu; Melemahnya kelembagaan lokal baik dari struktur organisasi maupun kultur (nilai-nilai), Kurangnya peran kelembagaan informal tersebut dalam pemerintahan secara umum. Kurang berfungsinya kelembagaan yang ada dalam melestarikan nilai-nilai tradisional yang ada di masyarakat. Hukum adat serta adat istiadat yang mulai tergerus zaman dan sudah jarang dipakai oleh masyarakat.

Fenomena di atas dipandang perlu dilakukan pengabdian kepada masyarakat berupa penyuluhan terhadap penguatan kelembagaan secara akademik dan evaluasi terhadap kondisi yang ada saat ini terkait dengan perubahan status desa menjadi Kampung adat di lingkungan Pemerintah Kabupaten Siak. Atas dasar itulah maka penulis tertarik untuk melakukan pengabdian tentang "PENGUATAN KELEMBAGAAN DESA ADAT DI KAMPUNG LUBUK JERING KECAMATAN SUNGAI MANDAU KABUPATEN SIAK".

\section{Masalah}

Kegiatan pengabdian ini dilakukan di Kampung Lubuk Jering Kecamatan Sungai Mandau Kabupaten Siak, beberapa permasalahan yang muncul dalam permasalahan yaitu: Melemahnya kelembagaan lokal baik dari struktur organisasi maupun kultur (nilai-nilai), Kurangnya peran kelembagaan informal tersebut dalam pemerintahan secara umum. Kurang berfungsinya kelembagaan yang ada dalam melestarikan nilai-nilai tradisional yang ada di masyarakat. Hukum adat serta adat istiadat yang mulai tergerus zaman dan sudah jarang dipakai oleh masyarakat.

Fenomena di atas dipandang perlu dilakukan pengabdian kepada masyarakat berupa penyuluhan terhadap penguatan kelembagaan secara akademik dan evaluasi terhadap kondisi yang ada saat ini terkait dengan perubahan status desa menjadi Kampung adat di lingkungan Pemerintah Kabupaten Siak. 


\section{METODE}

Kegiatan ini dilaksanakan dengan menggunakan metode penyuluhan. Dalam rangka penyadaran tentang pentingnya penguatan kelembagaan desa adat maka tim melakukan penyuluhan terhadap pemerintahan kampung adat, masyarakat dan generasi muda di kampung lubuk jering kecamatan sungai Mandau. Dalam penyuluhan ini dijelaskan tentang upaya-upaya yang perlu dilakukan untuk penguatan kelembagaan desa adat di kampung tersebut. Kegiatan ini dilakukan melalui dua tahapan kegiatan dari persiapan, konfirmasi sampai pada tahap pelaksanaan kegiatan. Adapun uraian masing-masing kegiatan dilaksanakan sebagai berikut:

\section{Tahap persiapan tim pengabdian}

Tahap persiapan digunakan oleh tim untuk mengadakan beberapa pertemuan guna pelaksanaan kegiatan di lapangan. Pertemuan pertama digunakan untuk membicarakan materi, tempat kegiatan, waktu, dan pembagian tugas anggota tim. Pertemuan kedua dilakukan untuk mendiskusikan program penyuluhan yang akan dilaksanakan. Semua kegiatan tersebut dilaksanakan di kampus Fisip UR.

\section{Tahap konfirmasi dan kegiatan}

Pada tahap ini tim melakukan pertemuan dengan pihak pemerintah kapung Lubuk Jering Kecamatan Sungai Mandau untuk memberitahukan akan adanya kegiatan pengabdian, apa tujuan dilakukan kegiatan di kantor, dan meminta kesediaan menjadwalkan waktu kegiatan.

\section{Tahap pelaksanaan kegiatan I}

Kegiatan yang pertama dilakukan adalah melakukan survei untuk melihat masalah yang berkaitan dengan keadaan kondisi eksisting kampung adat, kondisi eksisting masyarakat.

\section{Tahap pelaksanaan kegiatan II}

Kegiatan ini diawali dengan menyebarkan undangan kepada pemerintahan terkait, masyarakat serta para generasi muda kampung lubuk jering kecamatan sungai mandau.

\section{Tahap pelaksanaan kegiatan III}

Tahap ketiga adalah penyuluhan penguatan kelembagaan pemerintahan desa adat di kampung lubuk jering bagi pemerintahan kampung, masyarakat dan bagi generasi muda di kampung lubuk jering keacamatan sungai Mandau, yang semula sesuai dengan undangan yang telah disebarkan.

\section{PEMBAHASAN}

Undang-undang Nomor 06 Tahun 2014 tentang Desa memberikan kesempatan kepada masyarakat untuk mengatur dan mengurus rumah tangganya sendiri. Dalam upaya mewujudkan suatu proses pembangunan berkelanjutan yang partisipatif, pemerintah bersama-sama masyarakat berupaya untuk menghidupkan kembali kelembagaan yang sebelumnya tumbuh dan berkembang di masyarakat. Penguatan kelembagaan dan kelompok-kelompok lokal tersebut merupakan bentuk dari pemberdayaan masyarakat, dimana dapat menumbuhkan kesadaran tentang hak dan eksistensi masyarakat serta peningkatan kemampuan agar masyarakat mampu meraih akses terhadap sumber-sumber daya yang ada, baik ekonomi, sosial, politik dan kultural, serta berpartisipasi dalam semua tahapan proses pembangunan.

Pemerintahan Kampung adat yang sebelumnya hanya diakui sebagai kesatuan wilayah adat sekarang dihidupkan kembali dan diakui sebagai organisasi pemerintahan terendah. Pemerintahan desa yang telah berubah struktur sosial dalam masyarakat ini akibat diberlakukannya UU No. 5 Tahun 1979 Tentang Pemerintahan Desa dihapuskan dan dengan demikian diharapkan dengan menghidupkan kembali bentuk pemerintahan asli di Kabupaten Siak, partisipasi masyarakat untuk membangun kampung adat dapat ditumbuhkan lagi seiring dengan pengakuan kampung adat tersebut.

Kabupaten Siak merupakan salah satu Kabupaten yang dianggap paling tanggap terhadap gagasan dalam menghidupkan kembali Sistem Pemerintahan Tradisional yaitu Kampung adat. Untuk mewujudkan kampung adat, Pemerintah Kabupaten Siak telah mengalami proses yang cukup panjang sejak dikeluarkannya Undangundang Nomor 6 Tahun 2014 tentang Desa yang didalamnya memberikan peluang ditetapkannya desa adat. Adapun mekanisme penetapan Desa Adat adalah sebagai berikut :

1. Inventarisasi desa yang telah memiliki kode desa

2. Identifikasi dan pengkajian desa (Pemprov, Pemda Kabupaten dan Lembaga Adat/sebutan lain)

3. Penetapan Bupati dituangkan kedalam Ranperda. 
4. Penyusunan rancangan Peraturan Daerah disertai naskah akademis.

5. Pengajuan Nomor Registrasi kepada Gubernur

6. Pengajuan Kode Kampung adat kepada Mendagri

7. Penetapan Peraturan Daerah.

Penetapan Kampung adat yang dilakukan oleh Pemerintah Kabupaten Siak yaitu dengan mengeluarkan Perda Kabupaten No. 2 Tahun 2015 Tentang Penetapan Kampung adat di Kabupaten Siak yang diundangkan pada tanggal 15 Januari 2015 yang menjadi dasar hukum bagi pengaturan penetapan Pemerintahan Desa menjadi Pemerintahan Kampung adat. Delapan desa di Siak yang telah ditetapkan menjadi Kampung Adat itu adalah : Kampung adat lubuk jering, Kampung adat Tengah, Kampung adat Kuala Gasib, Kampung adat Akit Penyengat, Kampung adat Sakai Minas, Kampung adat Sakai Mandi Angin, Kampung adat Sakai Bekalar dan Kampung adat Sakai Libo Jaya.

Salah satu Kampung adat yang telah terbentuk Kelembagaannya adalah Kampung adat Lubuk Jering Kecamatan Sungai Mandau. Pembentukan Kelembagaan Kampung Adat Lubuk Jering adalah suatu upaya yang dilakukan Pemerintah Kabupaten Siak untuk menghidupkan kembali peran lembaga-lembaga yang ada di Kampung adat Lubuk Jering berdasarkan asal usul yang dimiliki. Dengan dihidupkannya kembali kelembagaan Kampung adat Lubuk Jering akan memberikan kewenangan yang lebih besar terhadap penyelenggaraan Kampung adat Lubuk Jering itu sendiri. Kewenangan yang diberikan tersebut merupakan kewenangan lokal yang dulunya tumbuh dan hidup didalam Kampung adat itu sendiri.

Adapun Lembaga Pemerintahan Kampung adat Lubuk Jering menurut Perda No. 2 Tahun 2015 Pemerintah Kabupaten Siak terdiri atas Pemerintah Kampung adat dan Badan Permusyawaratan Kampung adat (Bapekam). Pemerintah Kampung adat terdiri dari Penghulu dan Perangkat Kampung adat. Penghulu adalah kepala kampung adat sebagai penyelenggara pemerintahan kampung adat. Penghulu dalam melaksanakan pemerintahan kampung adat terutama dalam melaksanakan urusan-urusan yang menyangkut kedinasan, dibantu oleh perangkat kampung adat. Perangkat Kampung adat sebagaimana dimaksud terdiri dari: a. Sekretariat Kampung adat; b. Unsur kewilayahan; dan c. Pelaksana teknis lapangan. Sekretariat Kepenghuluan Adat terdiri dari: a. Kerani sebagai pimpinan sekretariat; dan b. Juru tulis, staf, atau unsur pembantu kerani.

Unsur kewilayahan adalah Pembantu Penghulu yakni kadus, rukun kampung dan rukun tetangga. Pelaksana teknis lapangan yaitu petugas Kampung adat yang melakukan suatu tugas tertentu dalam perkampungan Adat seperti urusan agama, keamanan, pengairan, pertanian, pemadaman kebakaran hutan dan lahan atau urusan lain yang jumlahnya disesuaikan dengan kebutuhan dan kondisi sosial budaya masyarakat setempat.

Disamping Penghulu dan perangkatnya, terdapat lembaga Badan Permusyawaratan Kampung adat yang menjalankan fungsi legislasi yang selanjutnya disebut Bapekam adalah lembaga yang melaksanakan fungsi pemerintahan yang anggotanya merupakan wakil dari penduduk Kampung Adat berdasarkan keterwakilan wilayah dan ditetapkan secara demokratis. Mengenai lembaga masyarakat Kampung adat Lubuk Jering saat ini tidak terjadi perubahan yang begitu siknifikan, pemerintah hanya membentuk beberapa lembaga saja dan mempertahankan lembaga yang ada seperti Lembaga Adat, Lembaga Adat pada Kampung Adat merupakan lembaga adat yang tak terpisahkan dari Lembaga Adat Melayu Riau yang ada di Kabupaten Siak.

Masyarakat hukum adat memiliki wilayah hukum adat dan hak atas harta kekayaan di dalam wilayah hukum adat tersebut serta berhak dan berwenang untuk mengatur, mengurus, dan menyelesaikan berbagai permasalahan kehidupan masyarakat Kampung adat berkaitan dengan adat dan istiadat dan hukum adat yang berlaku. Lembaga Adat Kampung adat merupakan mitra Pemerintah Kampung adat dan lembaga Kampung adat lainnya dalam memberdayakan masyarakat Kampung adat.

Untuk menghidupkan Kampung Adat haruslah ada peraturan berupa Peraturan Daerah dan Peraturan Bupati sebagai regulasi yang mengatur secara teknis pelaksanaan desa adat sesuai dalam Pasal 37 PP 43/2015. Penyelenggaraan pemerintahan Kampung adat tidak cukup dengan hanya diatur melalui Peraturan Daerah saja namun lebih spesifiknya perlu diatur melalui Peraturan Bupati. Belum adanya Peraturan Bupati tentu akan menghambat dalam pelaksanaannya.

Dari pembahasan diatas dapat ditarik benang suatu pemahaman bahwa keinginan untuk menghidupkan kembali Kelembagaan Kampung Adat tidak akan berjalan sesuai dengan yang diharapkan jika tidak adanya Peraturan Bupati yang mengatur tentang hal itu. Apabila regulasi tersebut telah dikeluarkan maka Kampung Adat akan bisa melaksanaakan penyelenggaraan pemerintahan sesuai petunjuk teknis yang ada di regulasi. Saat ini kelembagaan hanya terlaksana pada segi formalitas perubahan nama kelembagaan Kampung adat saja sedangkan dari segi subtansial belum terlaksana. 
Secara garis besar hasil kegiatan yang telah dicapai dalam pengabdian kepada masyarakat ini adalah sebagai berikut:

a. Materi tentang penguatan kelembagaan kampung adat pada umumnya dapat diterima dan dapat dipahami, serta mendapat respon dari peserta, yang ditandai dengan adanya peratanyaan-pertanyaan yang muncul.

b. Berdasarkan sikap dan pertanyaan yang diajukan dapat diketahui bahwa materi pengabdian sangat membantu dalam hal penguatan kelembagaan kampung adat di kampung lubuk jering.

c. Dari hasil pengabdian ini diharapkan akan ada tindak lanjut misalnya kampung Lubuk Jering menjadi desa binaan bagi Prodi Administrasi Publik Fisipol Universitas Riau.

d. Berdasarkan evaluasi dapat diketahui bahwa pada umumnya peserta dapat memahami bagaimana langkahlangkah yang harus dilakukan untuk mewujudkan terbentuknya kampung adat di kampung Lubuk Jering Kecamatan Mandau Kabupaten Siak.

\section{Ketercapaian sasaran}

Kegiatan pengabdian kepada masyarakat dalam rangka penguatan kelembagaan kampung adat di Kampung Lubuk Jering mendapat sambutan yang cukup baik. Pemerintah dan masyarakat desa pada umumnya belum begitu memahamai bagaimana menghidupkan kembali kampung adat susai dengan Undang-undang yang berlaku, karena selama ini status kampung adat hanya terbatas kepada pengakuannya saja.

Berikut merupakan faktor-faktor yang menghambat dan mendukung dalam kegiatan pengabdian kepada masyarakat di Kampung Adat Lubuk Jering Kecamatan Sungai Mandau Kabupaten Siak sebagai berikut:

\section{Faktor penghambat}

Faktor-faktor yang menjadi penghambat terlaksananya pengabdian kepada masyarakat di Kampung Adat Lubuk Jering Kecamatan Sungai Mandau adalah :

a. Pemahaman masyarakat akan pentingnya Kampung adat dalam menjaga keberlanjutan budaya, adat istiadat termasuk peningkatan kapasitas pemerintahan masih kurang. Hal ini ditandai dengan kurangnya pemahaman masyarakat dari segi system pemerintahan adat.

b. Pengetahuan aparatur pemerintahan kampung yang kurang baik secara teoritis dan praktek bagaimana mendorong masyarakat sadar akan pentingnya kampung adat.

c. Adanya sikap pesimis dari sebagian aparatur pemerintahan desa maupun masyarakat jika pengembangan desa menjadi kampung adat di daerahnya.

\section{Faktor pendukung}

Faktor-faktor yang mendukung terlaksananya pengabdian kepada masyarakat di Kampung Adat Lubuk Jering adalah:

a. Adanya dukungan positif dari pihak Pemerintah Kabupaten dengan membentuk Kampung Adat di Kampung Lubuk Jering Kecamatan Mandau.

b. Adanya antusiasme dari aparatur pemerintahan desa dalam pelaksanaan pengabdian kepada masyarakat.

\section{KESIMPULAN}

Pelaksanaan pengabdian masyarakat dalam rangka penguatan kelembagaan adat di Kampung Adat Lubuk Jering Kecamatan Mandau dapat disimpulkan telah berhasil memberikan penyuluhan. Keberhasilan ini antara lain ditunjukkan oleh :

a. Adanya kesesuain materi dengan kebutuhan aparatur pemerintahan desa dan masyarakat dalam usaha penguatan kelembagaan adat di Kampung Lubuk Jering Kecamatan Sungai Mandau Kabupaten Siak.

b. Adanya respon yang positif dari peserta, yang ditunjukkan dengan pertanyaan dan tanggapan yang diberikan selama pengabdian.

c. Sebagian besar peserta telah memahami arti pentingnya penguatan kelembagaan adat di Kampung Lubuk Jering Kecamatan Sungai Mandau Kabupaten Siak.

\section{REKOMENDASI}

Dari pertanyaan dan tanggapan peserta pengabdian dalam hal ini aparatur pemerintahan dan masyarakat dapat disarankan bahwa agar selalu termotivasi untuk melakukan perubahan sehingga semangat pembentukan kampung adat dapat dapat terwujud yang pada gilirannya akan terwujud pembangunan desa adat yang mandiri dan berkelanjutan. 


\section{DAFTAR PUSTAKA}

Ardika, W., \& D. Putra (ed). 2004. Politik Kebudayaan dan Identitas Etnik. Bali: Fakultas Sastra Universitas Udayana dan Balimangsi Press.

Baik, B. S., Wahono, Danisworo, Mohammad, \& Widjaja. 2002. Kembali ke Akar: Kembali Ke Konsep Otonomi Masyarakat Asli. Jakarta: FPPM H.

Bintaro. R. 1989. Dalam Interaksi Desa - Kota dan Permasalahannya. Jakarta. Ghalia Indonesia.

Dharmayuda, I. M. S. 2001. Desa Adat Kesatuan Masyarakat Hukum Adat di Bali. Denpasar: Upada Sastra.

Gunawan, D. H., A. Achdian \& B. A. Yulianto. 2013. JALAN BARU OTONOMI DESA: Mengembalikan Otonomi Masyarakat (Studi Kasus Bali, Sumatera Selatan dan Flores). Jakarta. Kemitraan Perpustakaan.

Lexy. J. M. 2002. Metodologi Penelitian Kualitatif. Bandung. PT Remaja Rosdakarya.

Martokusumo. 2000. Revitalisasi Kawasan Kota Sebuah Catatan dalam Pengembangan dan Pemanfaatan Kawasan Kota. Urban and reginal development institute.

Nirwanto,A. 2003. Otonomi Daerah Versus Desentralisasi Korupsi. Semarang. Aneka Ilmu.

Nurcholis, H. 2011. Pertumbuhan dan Penyelenggaraan Pemerintahan Desa,. Jakarta. Erlangga.

Peraturan Pemerintah Republik Indonesia Nomor 43 Tahun 2014 Tentang Peraturan Pelaksanaan Undang-Undang Nomor 6 Tahun 2014 Tentang Desa.

Peraturan Daerah Nomor 2 Tahun 2015 Tentang Penetapan Kampung Adat di Kabupaten Siak.

Sugiyono. 2009. Metode Penelitian Kuantitatif Kualitatif-R\&D. Alfabeta. Bandung.

Suryaningrat, B. 1980. Desa dan Kelurahan Menurut UU No 5 Tahun 1979. Jakarta.

UU No 6 Tahun 2014 Tentang Desa Peraturan Menteri Dalam Negeri No.52 Tahun 2014 Tentang Pedoman Pengakuan Dan Perlindungan Masyarakat Hukum Adat.

Widjaja, H. 2012. Otonomi Desa Merupakan Otonomi yang Asli, Bulat dan Utuh. Jakarta. Rajawali Press. 